Article

\title{
Experimental Evaluation of a Diesel Cogeneration System for Producing Power and Drying Aromatic Herbs
}

\author{
Luis Olmos-Villalba $^{1, * \mathbb{D}}$, Bernardo Herrera ${ }^{2}$, Anderson Gallego ${ }^{1} \mathbb{C}$ and Karen Cacua ${ }^{2}$ \\ 1 Institución Universitaria Pascual Bravo, Faculty of Engineering, Department of Mechanical, Calle 73 No. \\ 73a226, Medellín 050034, Colombia; ander.gallego91@gmail.com \\ 2 Advanced Materials and Energy group, Faculty of Engineering, Instituto Tecnológico Metropolitano, \\ Campus Fraternidad sótano M-2, Calle 54A No 1-30, Medellín 050034, Colombia; \\ bernardoherrera@itm.edu.co (B.H.); karencacua@itm.edu.co (K.C.) \\ * Correspondence: luis.olmos@pascualbravo.edu.co
}

Received: 23 July 2019; Accepted: 5 September 2019; Published: 19 September 2019

\begin{abstract}
The focus of this work was to evaluate the thermal performance of a cogeneration system used to produce power and dry aromatic herbs. The waste heat from the exhaust gases of the diesel engine was recovered to heat air using a thermosyphon heat exchanger. The heated air was employed in a convective tray dryer in order to dry Origanum vulgare, Mentha spicata, and Ocimum basilicum. The experiments were carried out at full load in a stationary compression ignition engine coupled to a generator. The maximum global energy efficiency of the cogeneration system was $40.14 \%$, and the effectiveness of the heat exchanger achieved $39 \%$.
\end{abstract}

Keywords: cogeneration; thermosyphon heat exchanger; aromatic herb drying; diesel fuel engine; waste heat recovery

\section{Introduction}

Energy is considered the basis of the productive, domestic, and commercial activities of rural communities. Consequently, worldwide government policies should propose more effective solutions in the pursuit of new technologies and processes, aiming at a continuous improvement of the energy efficiency and the use of primary energy sources $[1,2]$. In order to achieve such an objective, the options are to use renewable energy sources or recycle appropriately utilizing the energy that is currently being wasted [3].

Currently, in Colombia, the Non-Interconnected Zones (NIZs) outside the national electrical grid cover $52 \%$ of the national population [4,5]. In those areas, the main source of electricity is diesel generation, which represents $92 \%$ of the installed capacity; the remaining $8 \%$ corresponds to renewable sources [6]. Moreover, NIZs are mostly located in agricultural areas, where there is a high demand for drying processes because they have been implemented for a long time in order to extend the useful life of agricultural products such as aromatic plants [7].

Cogeneration is defined as the simultaneous generation of heat and power, and it offers an opportunity to increase the energy efficiency of diesel generators [8]. This technology not only saves energy, but it also reduces $\mathrm{CO}_{2}$ emissions $[9,10]$. The efficiency of a cogeneration system could be improved by up to $91 \%$ in comparison to that of diesel plants for electricity generation only [11-13].

A number of studies have been conducted to establish the performance and emissions of cogenerations systems; however, the literature does not include any report of experimental research into cogeneration systems for drying processes. Blumberg et al. [14] presented an energetic analysis of a cogeneration system for the co-production of power energy and syngas. In their work, the overall net 
efficiency was $37.4 \%$ generating power only; nevertheless, when they used cogeneration (i.e., generating power and substitute natural gas), the overall net efficiency reached 54.8\%. Abusoglu et al. [15] performed a thermodynamic analysis of a 25.32-MW diesel engine cogeneration system. They used the exhaust gases of the engine to produce the necessary shaft work for the compressor of a turbocharger turbine and to feed a boiler in order to generate water steam. The single generation efficiency in that case was $26.33 \%$, and the thermal efficiency of the overall plant was $40.7 \%$. Aussant et al. [16] used a $2-\mathrm{kW}$ internal combustion engine powered by natural gas to determine the feasibility of implementing a cogeneration system in single family houses. They found that the efficiency of the system increased from $30 \%-40 \%$ in single generation to $40 \%-65 \%$ in cogeneration using exhaust gases, the jacket water, and oil heat for heating water. Zhao et al. [13] tested and compared conventional generation with cogeneration using a 70-kW natural gas internal combustion engine. In their work, the thermal efficiency was increased from $24 \%-27 \%$ in conventional generation to $87 \%-91 \%$ in the cogeneration system. Lee et al. [12] developed an efficient and eco-friendly cogeneration system using a 2000-cc common-rail direct-injection (CRDI) diesel engine. The main results of their research were a thermal efficiency of $85.7 \%$ and a reduction of CO, NOx, and PM by $73.3 \%, 34.3 \%$, and $94 \%$, respectively. Lu et al. [17] studied a novel combined power and refrigeration system using Organic Rankine cycle (ORC) and a sorption system. They proposed and assessed the coolant energy and exhaust energy from a medium-duty diesel engine under various operating conditions for energy recovery. In their work, the thermal efficiency of the cogeneration was $47 \%$, and a reduction in specific fuel consumption from $205 \mathrm{~g} / \mathrm{kWh}$ to $180 \mathrm{~g} / \mathrm{kWh}$ was achieved.

In NIZs, the preservation of agricultural products plays an important role in the development of communities due to their location, especially in areas of crops of medicinal and aromatic plants. The production chain of aromatic herbs (AHs) in Colombia presents a growing trend, and one of its focal points is purchasing high-quality raw materials (dry herbs). Such quality depends on the dehydration technology that farmers can use in NIZs [18]. Dehydration processes for AHs depend on the technology of the dryer and the temperature and velocity of the drying air. The most common AHs in Colombia are Mentha piperita, Origanum vulgare, Rosmarinus officinalis, Mentha spicata, and Thymus vulgaris. In the drying process of AHs, the temperature is between 30 and $60^{\circ} \mathrm{C}$ [19-23] and the drying air velocity is between 0.2 and $4 \mathrm{~m} / \mathrm{s}$ [24-26]. Convective tray dryers are the most popular drying systems for AH dehydration, and they have been used by several authors [27-30].

On the other hand, a thermosyphon is a heat exchanger for efficient energy transfer. Such technology consists of an evacuated closed tube filled with a certain amount of working fluid; it is designed based on free convection, and it does not require mechanical equipment to move the fluid [31-33]. Thermosyphons are widely used in thermal engineering applications, mainly waste heat recovery, and their high efficiency is achieved thanks to the phase change of the working fluid. The heat transfer mechanism consists of boiling and evaporating a fluid in the evaporator section and transporting the vapor to the condenser section, where heat is recovered for an external source [31].

This paper presents a novel experimental study into a cogeneration system where the waste heat from the diesel engine is recovered. The aromatic herbs Origanum vulgare, Mentha spicata, and Ocimum basilicum are dried with waste energy recovered from exhaust gases using a heat exchanger with fifty copper thermosyphons. The cogeneration system can be available in Non-Interconnected Zones where diesel internal combustion engines are used for electricity generation and conservation processes for agricultural products are needed.

\section{Materials and Methods}

\subsection{Experimental Setup}

\subsubsection{Cogeneration System}

The cogeneration system consisted of a generator set coupled to a drying system, where the compression ignition engine runs at maximum power at a speed of $1800 \mathrm{rpm}$. The electric power 
output of the cogeneration equipment at full load was $12 \mathrm{~kW}$. A variable electrical resistance bench was used to set the engine load and a Coriolis sensor (Siemens, SITRANS 2100DI) was used to measure the diesel flow rate. Figure 1 shows a schematic diagram of the experimental setup. The temperatures of the exhaust gases and drying air inlet and outlet were measured using K-type thermocouples in the heat exchanger (T2, T3, T4, and T5 in Figure 1).

A bypass system, composed of three globe valves, was used to regulate the exhaust gas flow. Figure 1 shows the drying system which is comprised of a copper thermosyphon heat exchanger (HE), a convective tray dryer, and an air blower. Table 1 shows the technical characteristics of the equipment used in the cogeneration system.

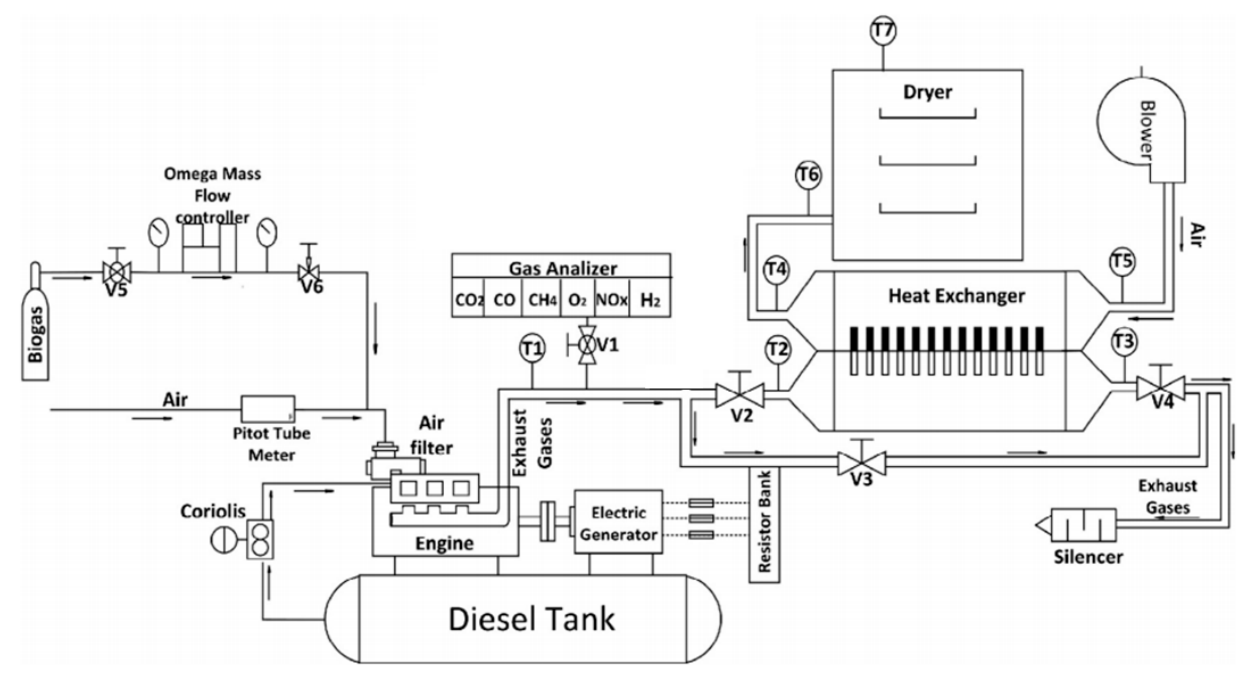

Figure 1. Schematic diagram of the experimental setup.

Table 1. Technical characteristics of the cogeneration system.

\begin{tabular}{|c|c|c|}
\hline Equipment & Characteristics & Specifications \\
\hline \multirow{2}{*}{ Generator set } & Compression ignition engine & $\begin{array}{c}\text { YANMAR 3TNE84, DI, four stroke, three cylinders, } \\
\text { naturally aspirated, water cooled, Diesel fuel } \\
\text { Rated power: } 14.8 \mathrm{KW}\end{array}$ \\
\hline & Generator & $\begin{array}{c}\text { MECC ALTE-ECO28 3L/2 } \\
31 \mathrm{kVA}(24.8 \mathrm{~kW}) \\
1800 \mathrm{RPM}\end{array}$ \\
\hline \multirow{3}{*}{ Drying system } & Heat exchanger & $\begin{array}{l}\text { Counter-flow air-exhaust gases, with fifty copper } \\
\text { thermosyphons filled with water. } \\
\text { Dimensions W } \times \mathrm{D} \times \mathrm{H}: 0.26 \times 0.76 \times 0.54 \mathrm{~m}\end{array}$ \\
\hline & Air blower & Centrifugal fan, $0.36 \mathrm{~kW}, 2100 \mathrm{RPM}$ \\
\hline & Dryer & $\begin{array}{l}\text { Convective three trays, Drying Chamber dimensions } \\
\qquad W^{*} \mathrm{D} * \mathrm{H}: 0.51^{*} 0.51 * 1.05 \mathrm{~m}\end{array}$ \\
\hline
\end{tabular}

\subsubsection{Thermosyphon Heat Exchanger Design}

In this work, a thermosyphon heat exchanger was designed, manufactured, and tested for heat recovery from exhaust gases at temperatures below $400{ }^{\circ} \mathrm{C}$. The starting point of the design was the heat transfer rate needed to heat the air for drying from room temperature up to the temperature required by the product, according to the steady state energy balance equation:

$$
\dot{Q}=\dot{m}_{\text {air }} C_{p, \text { air }}\left(T_{\text {drying }}-T_{\infty}\right)
$$


where $\dot{Q}$ is the heat transfer rate; $\dot{m}_{a i r}$, the mass flow rate of air for drying; $C_{p, a i r}$, the specific heat at constant pressure of the air at average temperature; $T_{\text {drying, }}$, the temperature for drying; and $T_{\infty}$ the room temperature. Knowing the mass flow rate $\left(\dot{m}_{f g}\right)$, the inlet temperature $\left(T_{f g, i}\right)$, and the composition of the diesel engine flue gases, the outlet temperature of this stream $\left(T_{f g, o}\right)$ was calculated as follows:

$$
T_{f g, o}=T_{f g, i}-\frac{\dot{Q}}{\dot{m}_{f g} C_{p, f g}}
$$

where $C_{p, f g}$ is the specific heat at constant pressure of the flue gases. Since the overall thermal resistance of thermosyphons is low, this resistance is assumed to be negligible and, thus, the heat exchanger is considered a counter-flow concentric tube heat exchanger. Based on that assumption, the well-known Effectiveness-NTU method [34] was used to calculate the heat exchange area. The number of thermosyphons was obtained by an iterative procedure and the thermosyphons were arranged in a staggered distribution, as shown in Figure 2. The length of the evaporator and the condenser were both $25 \mathrm{~cm}$, and no adiabatic zone was considered.

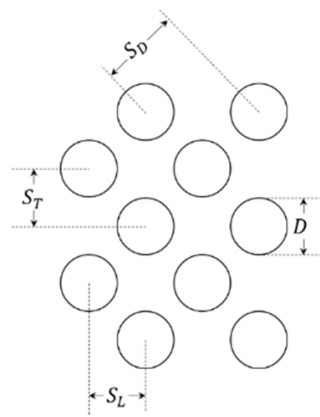

Figure 2. Scheme of distribution of thermosyphons in the heat exchanger.

Next, an average Nusselt number was calculated to compute the heat transfer coefficient of the entire thermosyphon bundle using a Zukauskas correlation [35].

Assuming that the heat rate in each thermosyphon $\left(\dot{Q}_{t}\right)$ is the ratio of the total heat rate $(\dot{Q})$ to the number of thermosyphons $(N)$, the total thermal resistance of a thermosyphon was calculated as

$$
R_{t}=\frac{\Delta T}{\dot{Q}}
$$

where $\Delta T$ is the difference between the inlet temperatures of the two gaseous fluids (air and flue gases). To verify the dimensions of the thermosyphon, the thermal resistance was compared with the series-parallel sum of thermal resistances in the thermosyphon, such as thermal resistance including the external convective resistance in the evaporator and condenser, conductive resistances in the wall and the evaporation, and condensation thermal resistances.

\subsubsection{Aromatic Herbs Used for Drying}

The AHs used in this drying process were Origanum vulgare, Mentha spicata, and Ocimum basilicum, which were grown in San Cristóbal (Medellín, Antioquia). Thermal Gravimetric Analysis (TGA, SDTQ600) was used to measure the initial moisture content of AHs.

Table 2 presents the initial moisture of the AHs and the load of each tray in the dryer. 
Table 2. Initial moisture of aromatic herbs (AHs) and load of each tray in the dryer.

\begin{tabular}{ccccc}
\hline AH & Initial Moisture (\%) & Tray Load 1 $\mathbf{( K g )}$ & Tray Load 2 $\mathbf{( K g )}$ & Tray Load 3 $\mathbf{( K g )}$ \\
\hline Origanum vulgare & 84 & 0.27 & 0.27 & 0.27 \\
Mentha spicata & 78 & 0.42 & 0.42 & 0.42 \\
Ocimum basilicum & 87.3 & 0.22 & 0.22 & 0.22 \\
\hline
\end{tabular}

Figure 3 shows the locations of different measurement points on the base of the dryer where the air velocity was determined with a Pitot tube anemometer and an ExtechHD350 differential manometer.

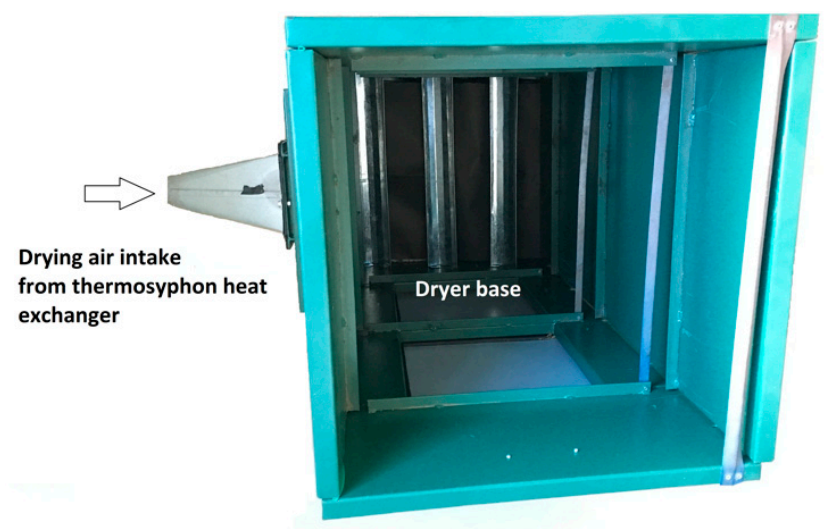

(a)

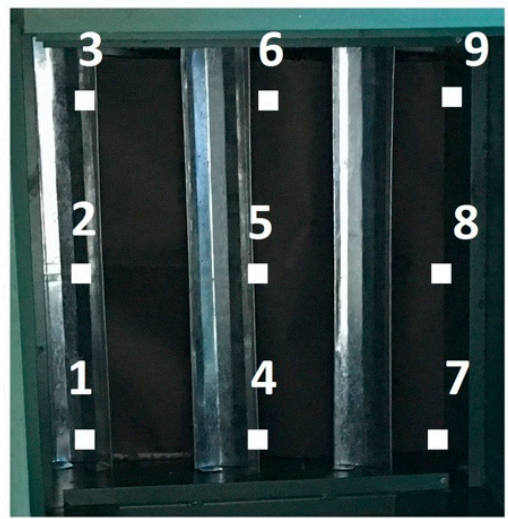

(b)

Figure 3. (a) Points for measuring drying air velocity on dryer base; (b) convective trays in the dryer.

To ensure a similar warming of the three trays, they were rotated every fifteen minutes. A KERN DS60K0.2 scale was used to measure the mass loss in each tray until the humidity of the AH was $10 \%$ or less. The initial position and the rotation of the trays are shown in Figure 4 . A FLUKE TI25 thermographic camera was used to show a qualitative temperature distribution of the AHs in the trays. Temperature measurement range, thermal sensitivity, accuracy, and emissivity of the thermographic camera were $-20{ }^{\circ} \mathrm{C}$ to $+350{ }^{\circ} \mathrm{C}, \leq 0.1{ }^{\circ} \mathrm{C}$ at $30{ }^{\circ} \mathrm{C}(100 \mathrm{mK}), \pm 2{ }^{\circ} \mathrm{C}$ or $2 \%$ and 0.9 , respectively.

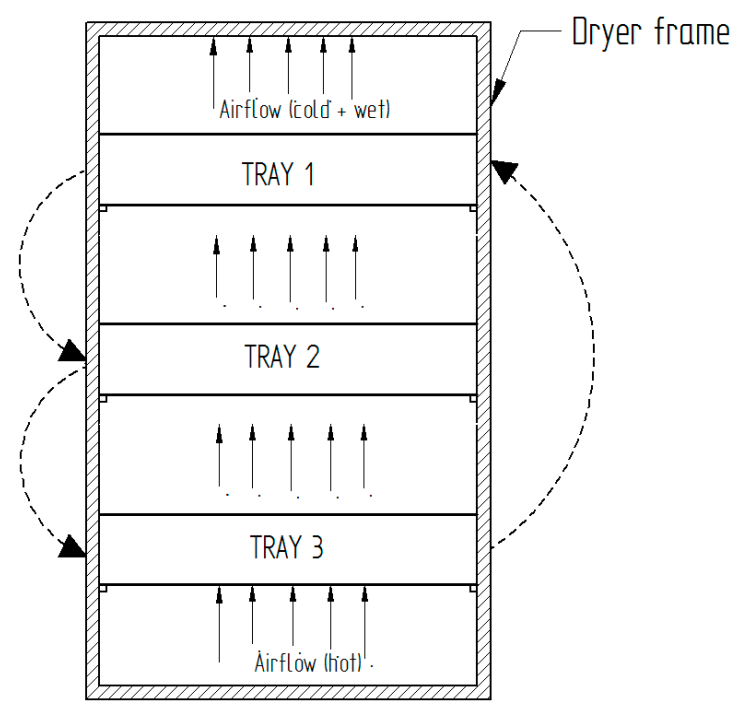

Figure 4. Initial position and rotation of the trays. 


\subsection{Experimental Procedure}

The cogeneration thermal efficiency $\left(\eta_{c}\right)$ was defined as the ratio of the sum of the generated output power $\left(\mathrm{N}_{\mathrm{E}}\right)$ and recovered heat $\left(q_{r}\right)$ to the energy contribution of the diesel, as follows in Equation (4):

$$
\eta_{c}=\frac{q_{r}+N_{e}}{\dot{\dot{m}_{D}} \dot{\dot{L} H} V_{D}}
$$

where $\dot{m}_{D}[\mathrm{~kg} / \mathrm{s}]$ is the diesel mass flow rate and $L H V_{D}[\mathrm{~kJ} / \mathrm{kg}]$ is the low heating value of diesel. The recovered heat $\left(q_{r}\right)$ was calculated with Equation (5).

$$
q_{r}=\dot{m}_{a} * C_{p, a} *\left(T_{a, o}-T_{a, i}\right)
$$

where $\dot{m}_{a}[\mathrm{~kg} / \mathrm{s}]$ is the drying air mass flow rate; $C_{p, a}$ the specific heat of drying air at constant pressure; $T_{a, o}$ the outlet drying air temperature; and $T_{a, i}$ the inlet drying air temperature. The effectiveness of the heat exchanger $\left(\varepsilon_{H E}\right)$ was calculated using Equation $(6)[36,37]$.

$$
\varepsilon_{H E}=\frac{q_{r}}{q_{\max }}
$$

where $q_{\max }$ is the heat transferred from the exhaust gases to the HE $\left(q_{\max }=\dot{m}_{e g} * C_{p, e g} *\left(T_{e g, i}-T_{e g, o}\right)\right.$, where $\dot{m}_{e g}[\mathrm{~kg} / \mathrm{s}]$ denotes the mass flow rate of exhaust gases; $C_{p, e g}$ the specific heat of exhaust gases at constant pressure; $T_{e g, 0}$ the outlet temperature of exhaust gases; and $T_{e g, i}$ the inlet temperature of the exhaust gases.

The analysis of drying process was assessed with the dimensionless moisture ratio (MR) and the moisture content. Such parameters can be determined with Equations (7) and (8), respectively [38]:

$$
\begin{gathered}
M R=\frac{M_{t}-M_{e}}{M_{o}-M_{e}} \\
\text { Moisture content }=\frac{M_{t}-M_{e}}{M_{e}}
\end{gathered}
$$

where $M_{t}[\mathrm{~kg}]$ is the mass of the drying product at time $\mathrm{t} ; M_{e}[\mathrm{~kg}]$ the dry mass of product; and $\mathrm{M}_{\mathrm{o}}[\mathrm{kg}]$ the initial mass of product.

The uncertainty was calculated using the manufacturer's specifications of each device. Equations (9)-(11) were used to calculate the uncertainty of the thermal efficiency, the recovered heat, and the effectiveness of the heat exchanger, respectively:

$$
\begin{gathered}
\frac{\Delta \eta}{\eta}=\sqrt{\left(\frac{\Delta q_{r}}{q_{r}}\right)^{2}+\left(\frac{\Delta N_{e}}{N_{e}}\right)^{2}+\left(\frac{\Delta m_{D}}{\dot{m}_{D}}\right)^{2}} \\
\frac{\Delta q_{r}}{q_{r}}=\sqrt{\left(\frac{\Delta \dot{m}_{a}}{\dot{m}_{a}}\right)^{2}+\left(\frac{\Delta(\Delta T)}{\Delta T}\right)^{2}} \\
\frac{\Delta \varepsilon_{H E}}{\varepsilon_{H E}}=\sqrt{\left(\frac{\Delta q_{r}}{q_{r}}\right)^{2}+\left(\frac{\Delta q_{\max }}{q_{\max }}\right)^{2}}
\end{gathered}
$$

Table 3 shows several uncertainty values which were calculated and obtained from the specifications of each device. 
Table 3. Associated uncertainty of some experimental variables.

\begin{tabular}{cc}
\hline Variable & Associated Uncertainty \\
\hline Thermocouples & $\pm 0.3^{\circ} \mathrm{C}$ \\
Coriolis mass flow rate & $\pm 8.7 \times 10^{-5} \mathrm{~kg} / \mathrm{s}$ \\
Pitot tube meter & $\pm 12.7 \times 10^{-4} \mathrm{~m}^{3} / \mathrm{s}$ \\
Generator efficiency & $88 \%$ at full load \\
Efficiency & $\pm 0.9 \%$ \\
Recovered heat & $\pm 0.6 \%$ \\
Effectiveness & $\pm 0.8 \%$ \\
\hline
\end{tabular}

\section{Results and Discussion}

\subsection{Cogeneration Performance and Heat Exchanger Performance}

The thermal efficiency of the generator set without cogeneration was $23 \%$. When the cogeneration system was included and the heat recovered from the exhaust gases of the compression ignition engine was used to heat air for drying, the thermal efficiency was increased up to $40.14 \%$ This is an important difference; however, further efficiency improvements could only be achieved using refrigeration systems which work with waste heat. Additionally, in cogeneration mode no increase in the diesel fuel consumption was identified, indicating no back pressure effects. The back pressure phenomenon is important because it can reduce the operating limits of the engine, increase the fuel consumption, and can lead to exhaust smoke due to incomplete combustion. However, additional studies with different types of restrictions in the exhaust systems must be done in order to study this important phenomenon in cogeneration systems [39-42]. Finally, the effectiveness of the heat exchanger was $39 \%$ on average, which is consistent with the values reported in the literature for this type of systems [37,43-45].

\subsection{Drying Analyses}

The traditional method for drying AHs uses solar energy. Such a process consists of leaving the products exposed to the sun. Depending on the AHs, it could take days or weeks. Convective dryers are a good option to reduce the drying time, but the process is intensive in terms of thermal energy consumption. In this study, waste thermal energy was used to heat air for drying Origanum vulgare, Mentha spicata, and Ocimum basilicum. The drying air velocities are shown in Table 4. Note that the drying air velocity is higher at the points near the air intake (points 1,2, and 3), which is due to a change in the direction of the drying air flow.

Table 4. Drying air velocity measured at different points on the dryer base.

\begin{tabular}{cccccc}
\hline $\begin{array}{c}\text { Measuring } \\
\text { Point }\end{array}$ & $\begin{array}{c}\text { Drying Air } \\
\text { Velocity (m/s) }\end{array}$ & $\begin{array}{c}\text { Measuring } \\
\text { Point }\end{array}$ & $\begin{array}{c}\text { Drying Air } \\
\text { Velocity }(\mathbf{m} / \mathbf{s})\end{array}$ & $\begin{array}{c}\text { Measuring } \\
\text { Point }\end{array}$ & $\begin{array}{c}\text { Drying Air } \\
\text { Velocity (m/s) }\end{array}$ \\
\hline 1 & 0.35 & 4 & 0.15 & 7 & 0.1 \\
2 & 0.45 & 5 & 0.25 & 8 & 0.2 \\
3 & 0.3 & 6 & 0.15 & 9 & 0.1 \\
\hline
\end{tabular}

Figure 5 shows the MR of Origanum vulgare, Mentha spicata, and Ocimum basilicum on tray 3 in the dryer. The time necessary to dry $0.81 \mathrm{~kg}$ of Origanum vulgare, $1.26 \mathrm{~kg}$ of Mentha spicata, and $0.66 \mathrm{~kg}$ of Ocimum basilicum and reach an MR under 0.1 was about 65, 90, and 105 min, respectively. 


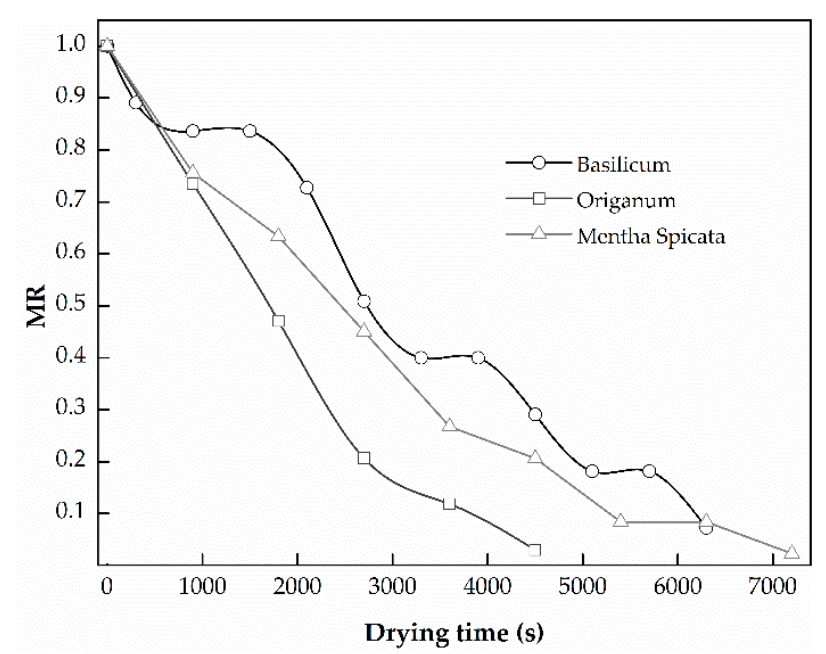

Figure 5. Moisture ratio (MR) behavior of Origanum vulgare, Mentha spicata, and Ocimum basilicum as a function of time.

The change in moisture content of the three AHs as a function of drying time is shown in Figure 6. The maximum moisture contents of Origanum vulgare, Mentha spicata, and Ocimum basilicum were $5.25 \mathrm{~kg}$-water/kg-solid, $3.54 \mathrm{~kg}$-water/kg-solid, and $6.86 \mathrm{~kg}$-water $/ \mathrm{kg}$-solid, respectively.

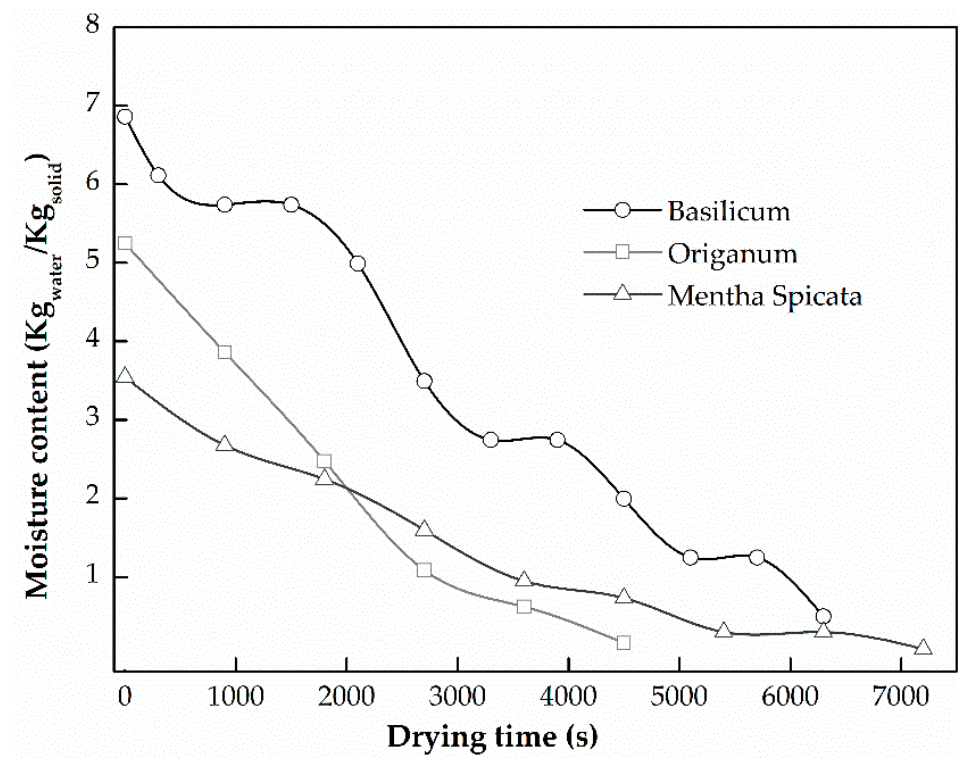

Figure 6. Moisture content behavior as a function of drying time.

The changes in the dimensionless moisture ratio of Mentha spicata in function of the time can be observed in Figure 7. During the drying process, the dimensionless moisture ratio decreased rapidly after $105 \mathrm{~min}$ in tray 1,95 min in tray 2, and $90 \mathrm{~min}$ in tray 3 . After these times, the drying process slowed down. Origanum vulgare and Ocimum basilicum showed the same trends due to the effect of extrinsic and intrinsic moisture. 


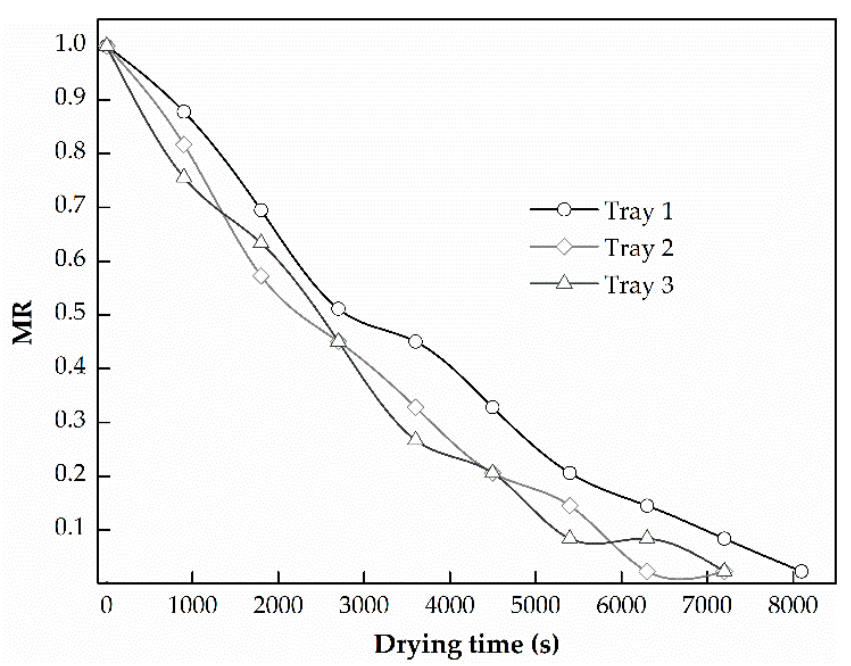

Figure 7. MR behavior of Mentha spicata in the three trays as a function of drying time.

Figure 8 shows thermographic images of the top and central trays during the drying process. On the top tray, a non-uniform temperature distribution can be observed qualitatively because the airflow was reduced at this point. The maximum inlet drying air temperatures in the dryer were $55^{\circ} \mathrm{C}, 60^{\circ} \mathrm{C}$, and $51^{\circ} \mathrm{C}$ when the inlet exhaust gases temperatures were $443{ }^{\circ} \mathrm{C}, 496^{\circ} \mathrm{C}$, and $428^{\circ} \mathrm{C}$, respectively. Figure 9 shows Mentha Spicata before and after the experiments. After the AH was dried, its color and smell were compared with a commercial product to verify the characteristics; however, for that purpose, additional studies on its organoleptic properties would have to be conducted.

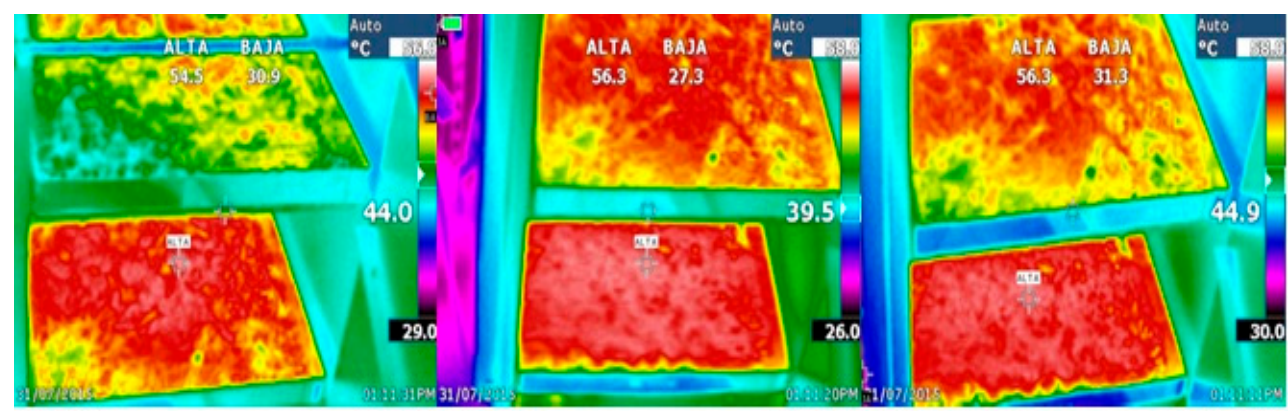

Figure 8. Qualitative temperature behavior of the two trays during the drying process.

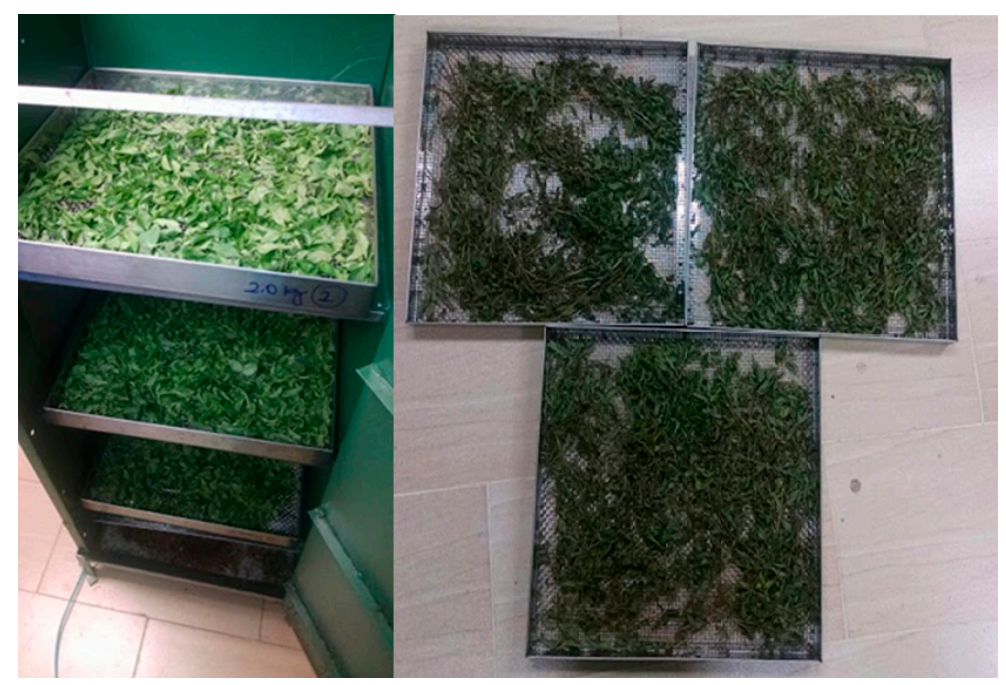

Figure 9. Mentha Spicata before (left) and after (right) drying. 


\section{Conclusions}

The cogeneration system described in this work allowed us to use the waste energy from the exhaust gases of the diesel engine for drying processes. Such a system can be available in NonInterconnected Zones where diesel internal combustion engines are used for electricity generation.

The maximum thermal efficiency of the cogeneration system was $40.14 \% \pm 0.9 \%$ when Origanum vulgare was dried.

The heat exchanger achieved an average effectiveness of $39 \% \pm 0.8 \%$, which could be improved by insulating the outer walls.

The drying times obtained in this study were below those reported in the literature with a similar drying air temperature and drying air velocity. Such improvement was possible because of the high efficiency of the heat exchanger in heating air with thermal energy recovered from its exhaust gases.

The drying system detailed here can be used to dry any product with drying air temperature requirements between 30 and $60^{\circ} \mathrm{C}$. The inlet drying air temperatures could be increased if the pipe between engine and dryer, and the thermosyphon walls were insulated, but in the case of aromatic herbs, the maximum temperature used in the drying process must be $60^{\circ} \mathrm{C}$ in order to maintain their aromatic and medicinal properties [19-23,46].

Author Contributions: Conceptualization, L.O.-V., B.H., A.G. and K.C.; methodology, L.O.-V. and K.C.; validation, L.O.-V., A.G. and K.C.; formal analysis, L.O.-V., B.H., A.G. and K.C..; investigation, L.O.-V., B.H., A.G. and K.C.; writing-original draft preparation, L.O.-V., B.H., A.G. and K.C.; writing—review and editing, L.O.-V., B.H., A.G. and K.C.

Funding: This research received no external funding agency.

Acknowledgments: The authors acknowledge the financial support received for this project from Instituto Tecnológico Metropolitano and Institución Universitaria Pascual Bravo in Medellín.

Conflicts of Interest: The authors declare no conflict of interest.

\section{References}

1. Rocha, M.S.; Andreos, R.; Simões-Moreira, J.R. Performance tests of two small trigeneration pilot plants. Appl. Therm. Eng. 2012, 41, 84-91. [CrossRef]

2. Kosowski, K.; Tucki, K.; Piwowarski, M.; Stępień, R.; Orynycz, O.; Włodarski, W. Thermodynamic Cycle Concepts for High-Efficiency Power Plants. Part B: Prosumer and Distributed Power Industry. Sustainability 2019, 11, 2647. [CrossRef]

3. Goyal, R.; Sharma, D.; Soni, S.L.; Gupta, P.K.; Johar, D. An experimental investigation of CI engine operated micro-cogeneration system for power and space cooling. Energy Convers. Manag. 2015, 89, 63-70. [CrossRef]

4. Instituto de Planificación y Promoción de Soluciones Energéticas Para Las Zonas no Interconectadas (IPSE). Available online: http://www.ipse.gov.co/ipse/informacion-institucional/ipse (accessed on 25 August 2015).

5. Behrentz, E.; Cadena, Á.; Delgado, R.; Espinosa, M.; Hernández, M.; Ovalle, K. Productos Analíticos Para Apoyar La Toma De Decisiones Sobre Acciones De Mitigación a Nivel Sectorial Oferta De Energía: Generación Eléctrica, Petróleo, Gas Y Carbón; Universidad de los Andes: Bogotá, Colombia, 2014.

6. Frias, O. Programa de Uso Racional y Eficiente de Energia y Fuentes no Convencionales_-PROURE. 2010. Available online: http://www1.upme.gov.co/DemandaEnergetica/MarcoNormatividad/plan.pdf (accessed on 6 September 2019).

7. Rolón, J.E. Optimización de Un Secador de Flujo Cruzado Para Plantas Aromáticas; Universidad Nacional de Colombia: Bogotá, Colombia, 2014.

8. Erdem, H.H.; Akkaya, A.V.; Dagdas, A.; Sevilgen, S.H.; Cetin, B.; Sahin, B.; Teke, I.; Gungor, C.; Atas, S.; Basak, M.Z. Renovating thermal power plant to trigeneration system for district heating/cooling: Evaluation of performance variation. Appl. Therm. Eng. 2015, 86, 35-42. [CrossRef]

9. Garnett, T. Food Refrigeration: What is the Contribution to Greenhouse Gas Emissions and How Might Emissions Be Reduced; Food Climate Research Network-Centre for Environmental Strategy University of Surrey: Guildford, UK, 2007. 
10. Maidment, G. Sustainable Innovation-A Technology Review. In Proceedings of the 1st IIR International Conference on Sustainability and the Cold Chain, Cambridge, UK, 29-31 March 2010.

11. Yingjian, L.; Qi, Q.; Xiangzhu, H.; Jiezhi, L. Energy balance and efficiency analysis for power generation in internal combustion engine sets using biogas. Sustain. Energy Technol. Assess. 2014, 6, 25-33. [CrossRef]

12. Lee, D.H.; Park, J.S.; Ryu, M.R.; Park, J.H. Development of a highly efficient low-emission diesel engine-powered co-generation system and its optimization using Taguchi method. Appl. Therm. Eng. 2013, 50, 491-495. [CrossRef]

13. Zhao, X.L.; Fu, L.; Zhang, S.G.; Jiang, Y.; Li, H. Performance improvement of a 70 kWe natural gas combined heat and power (CHP) system. Energy 2010, 35, 1848-1853. [CrossRef]

14. Blumberg, T.; Sorgenfrei, M.; Tsatsaronis, G. Design and Assessment of an IGCC Concept with $\mathrm{CO}_{2} \mathrm{Capture}$ for the Co-Generation of Electricity and Substitute Natural Gas. Sustainability 2015, 7, 16213-16225. [CrossRef]

15. Abusoglu, A.; Kanoglu, M. First and second law analysis of diesel engine powered cogeneration systems. Energy Convers. Manag. 2008, 49, 2026-2031. [CrossRef]

16. Aussant, C.D.; Fung, A.S.; Ugursal, V.I.; Taherian, H. Residential application of internal combustion engine based cogeneration in cold climate-Canada. Energy Build. 2009, 41, 1288-1298. [CrossRef]

17. Lu, Y.; Wang, Y.; Dong, C.; Wang, L.; Roskilly, A.P. Design and assessment on a novel integrated system for power and refrigeration using waste heat from diesel engine. Appl. Therm. Eng. 2015, 91, 591-599. [CrossRef]

18. Castro, D.; Diaz, J.; Serna, R. Cultivo y Producción de Plantas Aromáticas y Medicinales. 2013. Available online: https://conectarural.org/sitio/material/cultivo-y-producci\%C3\%B3n-de-plantas-arom\%C3\%A1ticasy-medicinales (accessed on 6 September 2019).

19. Hossain, M.B.; Barry-Ryan, C.; Martin-Diana, A.B.; Brunton, N.P. Effect of drying method on the antioxidant capacity of six Lamiaceae herbs. Food Chem. 2010, 123, 85-91. [CrossRef]

20. Doymaz, I. Thin-layer drying behaviour of mint leaves. J. Food Eng. 2006, 74, 370-375. [CrossRef]

21. El-Sebaii, A.A.; Shalaby, S.M. Experimental investigation of an indirect-mode forced convection solar dryer for drying thymus and mint. Energy Convers. Manag. 2013, 74, 109-116. [CrossRef]

22. García-Navarrete, F.J. Evaluación De Los Efectos Del Proceso De Secado Sobre La Calidad De La Stevia (Stevia Rebaudiana Bertoni) Y La Hierbabuena (Mentha Spicata); Universidad Nacional de Colombia: Bogotá, Colombia, 2014.

23. García, S.V.; Schmalko, M.E.; Tanzariello, A. Isotermas de absorción y cinética de secado de ciertas hortalizas y aromáticas cultivadas en misiones. RIA 2007, 36, 115-129.

24. Kaya, A.; Aydin, O. An experimental study on drying kinetics of some herbal leaves. Energy Convers. Manag. 2009, 50, 118-124. [CrossRef]

25. Śledź, M.; Nowacka, M.; Wiktor, A.; Witrowa-Rajchert, D. Selected chemical and physico-chemical properties of microwave-convective dried herbs. Food Bioprod. Process. 2013, 91, 421-428. [CrossRef]

26. Ayadi, M.; Mabrouk, S.B.; Zouari, I.; Bellagi, A. Kinetic study of the convective drying of spearmint. J. Saudi Soc. Agric. Sci. 2014, 13, 1-7. [CrossRef]

27. Sallam, Y.I.; Aly, M.H.; Nassar, A.F.; Mohamed, E.A. Solar drying of whole mint plant under natural and forced convection. J. Adv. Res. 2013, 6, 171-178. [CrossRef]

28. Jin Park, K.; Vohnikova, Z.; Pedro Reis Brod, F. Evaluation of drying parameters and desorption isotherms of garden mint leaves (Mentha crispa L.). J. Food Eng. 2002, 51, 193-199. [CrossRef]

29. Szumny, A.; Figiel, A.; Gutiérrez-Ortíz, A.; Carbonell-Barrachina, Á.A. Composition of rosemary essential oil (Rosmarinus officinalis) as affected by drying method. J. Food Eng. 2010, 97, 253-260. [CrossRef]

30. Antal, T.; Kerekes, B.; Sikolya, L. influence of drying on the volatile compounds of spearmint (Mentha spicata L.). 2011. Available online: http://www.uibcongres.org/imgdb/archivo_dpo11058.pdf (accessed on 6 September 2019).

31. Kamyar, a.; Ong, K.S.; Saidur, R. Effects of nanofluids on heat transfer characteristics of a two-phase closed thermosyphon. Int. J. Heat Mass Transf. 2013, 65, 610-618. [CrossRef]

32. Shanbedi, M.; Heris, S.Z.; Amiri, A.; Baniadam, M. Improvement in Heat Transfer of a Two-Phased Closed Thermosyphon Using Silver-Decorated MWCNT/Water. J. Dispers. Sci. Technol. 2014, 35, 1086-1096. [CrossRef]

33. Noie, S.H.; Heris, S.Z.; Kahani, M.; Nowee, S.M. Heat transfer enhancement using Al2O3/water nanofluid in a two-phase closed thermosyphon. Int. J. Heat Fluid Flow 2009, 30, 700-705. [CrossRef] 
34. Incropera, F.P.; DeWitt, D.P.; Bergman, T.L.; Lavine, A.S. Fundamentals of Heat and Mass Transfer, 6th ed.; John Wiley \& Sons: Chichester, UK, 2006.

35. Žukauskas, A. Heat Transfer from Tubes in Crossflow. Adv. Heat Transf. 1972, 8, 93-160.

36. Danielewicz, J.; Sayegh, M.A.; Śniechowska, B.; Szulgowska-Zgrzywa, M.; Jouhara, H. Experimental and analytical performance investigation of air to air two phase closed thermosyphon based heat exchangers. Energy 2014, 77, 82-87. [CrossRef]

37. Mroue, H.; Ramos, J.B.; Wrobel, L.C.; Jouhara, H. Experimental and numerical investigation of an air-to-water heat pipe-based heat exchanger. Appl. Therm. Eng. 2015, 78, 339-350. [CrossRef]

38. Gulcimen, F.; Karakaya, H.; Durmus, A. Drying of sweet basil with solar air collectors. Renew. Energy 2016, 93, 77-86. [CrossRef]

39. Sapra, H.; Godjevac, M.; Visser, K.; Stapersma, D.; Dijkstra, C. Experimental and simulation-based investigations of marine diesel engine performance against static back pressure. Appl. Energy 2017, 204, 78-92. [CrossRef]

40. Sivaram, A.R.; Rajavel, R.; Jayakumar, N.; Vinothkumar, M. Exhaust back pressure effect on the performance features of a diesel engine. Arpn J. Eng. Appl. Sci. 2017, 12, 5353-5356.

41. He, W.; Wang, S. Thermoelectric performance optimization when considering engine power loss caused by back pressure applied to engine exhaust waste heat recovery. Energy 2017, 133, 584-592. [CrossRef]

42. Burnete, N.; Moldovanu, D.; Baldean, D.L.; Kocsis, L. Studies Regarding the Influence of Exhaus Backpressure on the Performances of a Compression Ignited Engine. In Proceedings of the European Automotive Congress EAEC-ESFA 2015, Bucharest, Romania, 25-27 November 2015; Andreescu, C., Clenci, A., Eds.; Springer: Berlin/Heidelberg, Germany, 2015; pp. 141-149.

43. Jouhara, H.; Meskimmon, R. Experimental investigation of wraparound loop heat pipe heat exchanger used in energy efficient air handling units. Energy 2010, 35, 4592-4599. [CrossRef]

44. Jouhara, H.; Merchant, H. Experimental investigation of a thermosyphon based heat exchanger used in energy efficient air handling units. Energy 2012, 39, 82-89. [CrossRef]

45. Noie, S.H. Investigation of thermal performance of an air-to-air thermosyphon heat exchanger using $\varepsilon-N T U$ method. Appl. Therm. Eng. 2006, 26, 559-567. [CrossRef]

46. Tonguino Borja, M.I. Determinación De Las Condiciones Óptimas Para La Deshidratación De Dos Plantas Aromáticas; Universidad Tècnica del Norte: Ibarra, Ecuador, 2011. 